\section{Amino Acid Activation in Ciona Ovary and Developing Egg}

One of the first steps in protein synthesis is the 'activation' of the amino acids. The activation occurs by specific enzymes catalysing the formation of amino-acyl adenylate and the transfer of amino-acyl moiety from AMP to specific RNA acceptors 1,2 . Leucine dependent ATPpyrophosphate exchange and the leucine hydroxamate formation has been demonstrated in Xenopus $\mathrm{egg}^{3,4}$, and glycine activation has been found in sea urchin ${ }^{5}$.

The present paper reports the rate of activation of some natural amino acids by amino-acyl-hydroxamate formation in the presence of enzyme extract from Ciona

Table I. Amino acid activation in Ciona egg (m$\mu$ moles of hydroxamate/mg proteins)

\begin{tabular}{|c|c|c|c|c|c|c|}
\hline & \multicolumn{2}{|c|}{ Oocytes } & \multicolumn{2}{|c|}{ Unfertilized eggs } & \multicolumn{2}{|c|}{ Fertilized $30 \mathrm{~min}$} \\
\hline & $\begin{array}{l}\text { No. } \\
\text { exp. }\end{array}$ & Means \pm s.e. & $\begin{array}{l}\text { No. } \\
\text { exp. }\end{array}$ & Means \pm s.e. & $\begin{array}{l}\text { No, } \\
\text { exp. }\end{array}$ & means \pm s.e. \\
\hline Glycine & 8 & $22.1 \pm 1.00$ & 5 & $16.5 \pm 0.50$ & 5 & $30.1 \pm 0.60$ \\
\hline Histidine & 10 & $28.4+1.27$ & 4 & $18.1 \pm 0.31$ & 4 & $27.8 \pm 0.32$ \\
\hline Leucine & 8 & $18.0 \pm 0.88$ & 3 & $9.7 \pm 0.36$ & 4 & $22.1 \pm 0.42$ \\
\hline Arginine & 4 & $13.9 \pm 0.42$ & & & & \\
\hline Tyrosine & 1 & 31,0 & & & & \\
\hline Alanine & 1 & 25.0 & & & & \\
\hline
\end{tabular}

The reaction mixture contains in $1 \mathrm{ml}: 200 \mu$ moles Tris buffer, $\mathrm{pH}$ $7.8 ; 10 \mu$ moles $\mathrm{MgCl}_{2} ; 10 \mu$ moles ATP (adjusted to $\mathrm{pH} 7.8$ with $\mathrm{KOH}$ ); $1 \mu$ mole salt-free $\mathrm{NH}_{2} \mathrm{OH}, 10 \mu$ moles L-amino acids, $0.5 \mathrm{ml}$ of the enzyme fraction ( $2 \mathrm{mg}$ protein).

Time of incubation was $30 \mathrm{~min}$ at $37^{\circ}$. The values represent the difference of hydroxamate formation, in the presence and in the absence of added amino acid in the incubation mixture.

Table II. Glycine activation in Ciona eggs ( $\mu$ moles hydroxamate/mg protein)

\begin{tabular}{|c|c|c|c|}
\hline & $\begin{array}{l}\text { No. of } \\
\text { experiments }\end{array}$ & Means & $P$ \\
\hline Oocytes & 8 & $22.1 \pm 1.00$ & $4.00<0.01$ \\
\hline Unfertilized egg & 5 & $16.5 \pm 0.50$ & $17.00<0,01$ \\
\hline Fertilized $30 \mathrm{~min}$ & 5 & $30.1 \pm 0.60$ & $3.00<0.02$ \\
\hline 8-16 blastomeres & 6 & $36.7 \pm 2.00$ & $1.50<0.10$ \\
\hline Early blastula & 10 & $31.7 \pm 3.70$ & $2.20<0.05$ \\
\hline Early gastrula & 7 & $42.4 \pm 3.00$ & $0.75<0.40$ \\
\hline Late gastrula & 10 & $46.3 \pm 4.30$ & $3.10<0.01$ \\
\hline Neurula & 7 & $32.0 \pm 1.96$ & \\
\hline
\end{tabular}

For assay methods, see Table I. ovary and egg in early stages of development. The enzyme extract was prepared as previously described ${ }^{6}$. The methods used for assaying hydroxamate formation were according to HOAGLAND et al. ?

The amounts of the activated amino acids present in the ovary, the unfertilized egg, and the egg $30 \mathrm{~min}$ after fertilization, are shown in Table I. The results show that the activation rate of amino acids is high during the oogenesis, decreases in the mature unfertilized egg and increases after fertilization. The increase after fertilization agrees with autoradiographic and biochemical investigations which show an increased incorporation of labelled amino acids after fertilization ${ }^{8 m 10}$.

Recent reports suggest also that messenger RNA becomes evident in the ribosomes at fertilization ${ }^{11,12}$.

Table II shows the glycine activation during the early development. The activity of glycine activating enzymes increases during the segmentation period and comes up to a peak at gastrulation. At neurulation the amount of activated glycine decreases. The high activity of activating enzymes at gastrulation agrees with the reported synthesis of new enzymic proteins in Ciona egg at this stage ${ }^{13,14}$. Also in Ciona egg autoradiographic research showed that glycine incorporation occurs at the gastrula stage, especially into the mesenchyma and the presumptive neural territory ${ }^{9}$.

More details on methods and results will be published elsewhere ${ }^{15}$.

Riassunto. E stata studiata la attivazione di alcuni amini acidi negli ovociti nell'uovo vergine e nell'uovo fecondato di Ciona intestinalis. L'andamento della attivazione della glicina è stato seguito sino alla neurulazione. Il quantitativo di amino acidi attivati e minimo nell'uovo vergine, esso aumenta rapidamente dopo la fecondazione. Durante la gastrulazione la attivazione della glicina raggiunge i valori maggiori.

M. MOLINaro

Istituto di Zoologia, Università di Palermo (Italy). December 16, 1963.

${ }^{1}$ M. B. Hoagland, Biochem. biophys. Acta 16, 288 (1955).

P. Berg, F. H. Bergman, E. J. Ofengand, and M. Dieckmann, J. biol. Chem. $23 \%, 1778$ (1961).

s E. M. Devchar, Exp. Cell Res. 25, 364 (1961).

E. M, Deuchar, Exp. Cell Res. 26, 568 (1962).

- E. Scarano and E. Magcto, Exp. Cell Res. 12, 403 (1957)

6. Molinaro, Rend. Accad. Naz. Lincei 34, s. 8, 563 (1963).

"M. B. Hoagland, E. B. Keller, and P.C. ZaMrCniK, J. biol. Chem. 218, 345 (1956).

8. Ge Reverberi, W. G. Verly, C. Mansueto, and T. D'Anna, Acta embryol. morphol, exper. 3, 202 (1960).

- C. Mansueto, Acta embryol. morphol. exper. 5, 195 (1962).

10 A. Monroy, Exper. 16, 114 (1960).

11 M. NEmer, Biochem. biophys. Res. Comm. 8, 511 (1962).

12 F. H. Wilt and T. Hultin, Biocherm. biophys. Res. Comm, 9, 313 (1962).

19 A. Minganti, Pubbl. Staz, Zool. Napoll 83,52 (1951).

14 A. Minganti, Pubbl. Staz. Zool. Napoli 25, 9 (1954).

${ }^{16}$ The author wishes to thank Professor G. Reverberi for his suggestions and helpful advice during this work. 